\title{
SFERA NICZYJA JAKO ŹRÓDŁO ŻYCIA PSYCHICZNEGO: NIETZSCHE, SCHELER, WITTGENSTEIN, GOFFMAN
}

Słowa kluczowe: znajomość innego, poznanie ja, przeżycia, emocje, doznania, gra językowa, gra społeczna, Nietzsche, Scheler, Wittgenstein, Goffman Keywords: knowledge of other, knowledge of I, experiences, emotions, sensations, language game, social game, Nietzsche, Scheler, Wittgenstein, Goffman

Pytania zarówno o wiedzę podmiotu o sobie, jak i o znajomość stanów psychicznych innego człowieka zadawane były przez filozofów w różnych epokach i dawały początek nigdy nierozstrzygniętym dywagacjom. W wieku XX nie było inaczej. Pytania o możliwość poznania ja, czy to własnego, czy też cudzego, sytuują się pośród najczęściej stawianych przez fillozofów współczesnych. I choćby przez to już, że podejmuje je wielu myślicieli różnej proweniencji, nie znajdują zgodnych odpowiedzi. Mimo to da się dostrzec, że w XX wieku pojawia się koncepcja szczególnie doniosła, a znaleźć ją można - co ciekawe - wśród przedstawicieli trendów myślowych powszechnie uznawanych za odmienne. Jest to koncepcja, w której

* Katarzyna Gurczyńska-Sady - dr hab., prof. UP, zatrudniona w Instytucie Filozofii i Socjologii Uniwersytetu Pedagogicznego im. KEN w Krakowie.

Address for correspondence: Katarzyna Gurczyńska-Sady, ul. Kremerowska 14/6, 31-130 Kraków. E-mail: Katarzyna.sady@gmail.com. 
źródło życia psychicznego ja umiejscawia się poza nim: w sferze, którą w tym artykule będziemy określać mianem bezosobowej sfery niczyjej.

W tradycyjnym ujęciu życie psychiczne, czy też - jeśli ktoś woli - życie duchowe jednostki toczy się w ,odosobnieniu” zwanym jej wnętrzem. Uważa się, że ze względu na swój skryty charakter nie jest ono bezpośrednio dane innym podmiotom, które mogą - co najwyżej - trafnie się go domyślać na podstawie ruchów ciał (zachowań niewerbalnych) i wyznań (zachowań werbalnych). Swobodny dostęp jednostka ma wyłącznie do własnych przeżyć (doznań, emocji, odczuć, myśli itd.). Wnętrze innego człowieka nie jest nam nigdy bezpośrednio dane. W wieku XX (choć nie po raz pierwszy) ten tradycyjny pogląd poddano $\mathrm{z}$ różnych stron gruntownej krytyce.

Uznaje się znajomość własnego ja, dokonaną na podstawie introspekcji, za zbyt przecenioną w filozoficznej tradycji, z kolei znajomość stanów psychicznych innych ludzi za niedocenioną. Izolowane wnętrze jednostki zostaje (wielogłosowo) okrzyknięte mitem, a nieznajomość (umysłów lub dusz) innych ulega zakwestionowaniu. Jako owoc tej krytyki zarysowuje się tendencja odwrotna: uznaje się wiedzę o przeżyciach innego człowieka za daną i dostrzega się problematyczność samowiedzy. W odpowiedzi na tę rewolucyjną tendencję pojawia się koncepcja, która znajomość zarówno własnego, jak i cudzego ja wyjaśnia, wprowadzając element umożliwiający owo poznanie i umieszczony poza którymkolwiek z nich. Jest nim wspomniana bezosobowa sfera niczyja (nienależąca ani do ja, ani do ty) - ponadindywidualna macierz znajomości własnych i cudzych przeżyć (emocji, doznań, myśli), czyli życia psychicznego konkretnych indywiduów.

W niniejszym artykule autorka stawia sobie za zadanie wskazanie genezy idei owej bezosobowej sfery niczyjej, jej głównych cech charakterystycznych i problemów, które jej wprowadzenie rozwiązuje. Opis ów zostanie oparty na poglądach filozofów, którzy - ze względu na prezentowane nurty - pozostawali sobie obcy i nie wpływali bezpośrednio na siebie. To pozwoli podkreślić uniwersalność owej sfery, obecność wykraczającą poza wąski krąg myślicieli jednej opcji filozoficznej. Przywołane zostaną poglądy Maxa Schelera i Ludwiga Wittgensteina, filozofów, którzy w swoich rozważaniach dotyczących znajomości innego człowieka doszli - w pewnej mierze - do wspólnych wniosków, choć drugi z nich, Wittgenstein, zaszedł w swoich wyjaśnieniach nieco dalej niż pierwszy. Uchwycenie tego, na czym polega jego „krok do przodu” w stosunku do osiągnięć Schelera, pozwoli wyłowić najbardziej charakterystyczne cechy omawianej tu bezosobowej sfery ni- 
czyjej. Dla klarowności wywodu rozważania niniejsze zostaną wzbogacone o uwagi Fryderyka Nietzschego i Erwinga Goffmana, których poglądy rzucą dodatkowe światło na prezentowane idee Schelera i Wittgensteina.

Wprowadzenie do problemu - wstępne zarysowanie tego, czym jest bezosobowa sfera niczyja, będąca matrycą znajomości przeżyć innego człowieka i swoich własnych, zaczniemy od uwag Nietzschego, u którego pojawia się ona w formie zalążkowej, ale charakterystycznej dla swojej postaci dojrzałej.

\section{Nietzsche - świadomość uwarunkowana społecznie}

Mirosław Żelazny pisze o Nietzschem jako o jednym ,z pierwszych nowożytnych filozofów, który zauważył, że kwintesencję bycia człowiekiem nie stanowi jakaś niezależna od świata dusza" (Żelazny, 2007, s. 114). Tezę tę należy potraktować jako najistotniejsze założenie dla omawianych tu rozważań. Idea człowieka jako istoty, która posiada duszę pochodzącą ,nie z tego świata", zostaje przez Nietzschego odrzucona, a na jej miejsce pojawia się koncepcja istoty uwarunkowanej swym ziemskim trwaniem. Istota owa zamiast duszy uposażona jest trojako: przede wszystkim w popęd, a następnie w świadomość i moralność. W popęd zaopatrzyła ją przyroda, a świadomość i moralność pojawiają się ze względu na procesy uspołecznienia.

Pojęcie świadomości - najbardziej ze względu na prowadzone rozważania interesujące - pojawia się w twórczości owego znakomitego myśliciela końca XIX wieku jako antyteza świadomości Kartezjańskiej. W miejsce samoprzejrzystej substancji o charakterze duchowym Nietzsche wprowadza pojęcie świadomości jako substancji organicznej, w przeciwieństwie do duszy, pozbawionej możliwości samooglądu. W nawiązaniu do teorii Darwina myśliciel przedstawia ją jako organ przystosowawczy, który powstaje u człowieka w związku ze zmianą warunków życia. Będąc wyrwany ze stanu naturalnego i ,wtłoczony” w ,klatkę” społeczeństwa - jak każda istota żywa - człowiek szuka dróg przystosowania się do tego, co dlań nowe. Odpowiedzią na to zapotrzebowanie jest właśnie świadomość. Organ - jak widać - względnie w człowieku nowy.

Świadomość - podkreślmy to - pojawia się w momencie, kiedy zwierzę (którym był człowiek) ulega procesowi socjalizacji. Istota ludzka, będąc siłą zmuszona do życia w nowych warunkach - żyjąc we wspólnocie-potrzebuje 
organu, który takie wspólnotowe życie umożliwi i usprawni. I to właśnie decyduje o charakterze świadomości. Służy ona - podobnie jak moralność - interesom grupy, nie jednostki. Dlatego też - wbrew tradycji kartezjańskiej - nie daje bezpośredniej samowiedzy. Jest świadomością grupy: służy poznaniu tego, czego chcą, nie chcą, czują, wolą itd. inni.

[...] świadomość rozwinęła się w ogóle tylko pod naciskiem potrzeby powiadamiania się - że pierwotnie tylko pomiędzy człowiekiem i człowiekiem (między rozkazującym a słuchającym w szczególności) była pożyteczna i rozwinęła się także tylko w stosunku do stopnia jej pożyteczności. Świadomość jest właściwie tylko siecią, łączącą człowieka z człowiekiem, - tylko jako taka musiała się rozwinąć: pustelniczy i drapieżny człowiek jej nie potrzebował (Nietzsche, thum. 1910-1911, s. 308).

Człekokształtne istoty żywe - zgodnie z naturalną historią ludzkości, którą kreśli na kartach swoich książek Nietzsche - tracąc możliwość życia na swobodzie, zostają zmuszone utworzyć - uhierarchizowane - stado. Istota żywa tym sposobem zostaje zmuszona do życia pośród innych, co z kolei rodzi potrzebę porozumiewania się. I ta właśnie realizuje się za pomocą świadomości tego, co przeżywają inni. Dlatego też świadomość daje poznanie, ale poznanie innych. Powstając w każdej jednostce, łączy grupę.

[...] nie tylko mowa służy za most między człowiekiem i człowiekiem, lecz i spojrzenie, uścisk, gest; uświadomienie naszych wrażeń zmysłowych w nas samych, siła utrwalania ich i niejako stawiania poza obrębem siebie, wzrasta $\mathrm{w}$ miarę, jak rósł mus powiadamiania o nich innych przez znaki. [...] dopiero jako zwierzę społeczne nauczył się człowieka uświadamiać sobie (Nietzsche, tłum. 1910-1911, s. 308).

W fragmencie tym ważna jest kolejność. Świadomość przede wszystkim służy interesom grupy. Dla niej powstaje. A dopiero potem służy jednostce - ale i wtedy w perspektywie uświadamiania sobie tego, co w niej uniwersalne, wspólne grupie, z którą ta jest związana. Odpowiada na powstałą potrzebą porozumiewania się, powiadamiania innych. Pozwala na refleksję dotyczącą tego, co dzieje się $w$ jednostce, ale w związku z grupą. Powstająca w ten sposób wiedza o ja jest wiedzą „odbitą”, pochodzącą spoza niego samego. Jest samowiedzą w kontekście tego, co czują, myślą, wolą itd. inni członkowie grupy. Jeśli więc świadomość coś odzwierciedla, 
to to, co dla grupy będzie zrozumiałe, dla niej uniwersalne, nie zaś wobec niej autonomiczne (własne, prywatne i nieznane).

Świadomość nie przynależy właściwie do indywidualnej egzystencji człowieka, raczej do tego, co jest w nim naturą gromadną i stadną, że jak z tego wynika, rozwinęła się ona subtelnie tylko ze względu na gromadny i stadny pożytek i że w następstwie tego, każdy z nas, przy najlepszej woli rozumienia siebie samego najmożliwiej indywidualnie, „poznania samego siebie”, będzie uświadamiał sobie jednak właśnie tylko to, co jest w nim nieindywidualne, swoją „średniość” (Nietzsche, tłum. 1910-1911, s. 309).

To, co w tym artykule będziemy nazywać bezosobową sferą niczyją, ma zarysowane tu cechy Nietzscheańskiej świadomości. Zbierzmy je krótko. Świadomość nie służy poznaniu tego, co w ja indywidualne, właściwe tylko jemu samemu. Powstaje po to, by ludzi mogli się nawzajem rozumieć, trafnie odgadywać zamierzenia, nastroje, nadzieje, lęki czy myśli, nie zaś po to, by jednostce zapewnić „sam na sam” ze sobą. Świadomość sprawia, że inny człowiek w swoich zachowaniach jest dla ja zrozumiały. I to samo odnosi się do rozumienia ja przez innych. Dając poznanie własnego ja, czyni to w kontekście tego, co jest zrozumiałe dla pozostałych członków grupy i co - z różnych względów - jest dla nich ważne. Sprawia zatem, że moje przeżycia są innym znane, czyni mnie wobec innych przewidywalnym, daje innym wgląd w moje życie psychiczne. Sprawia, że moje zachowanie, posunięcia, motywy działania stają się dla innych czytelne. Można też powiedzieć, że świadomość odzwierciedla wyłącznie nieswoiste dla ja rysy. Nie własne, ponadindywidualne, bo tylko te będą dla innych zrozumiałe.

\section{Schelerowska bezosobowa sfera niczyja}

Kwestia istnienia bezosobowej sfery niczyjej, będącej źródłem poznania zarówno ty, jak i ja, pojawia się u Schelera ze względu na problematykę, którą określa on jako zagadnienie, ,istotowych i poznawczych podstaw powiązania ludzkich Ja i ludzkich dusz" (Scheler, tłum. 1980, s. 318). Problem ten, poza sensem, który ujmuje jako ontyczno-metafizyczny, czy też teoriopoznawczy, jest problemem życiowym. Scheler określa go jako ważny „dla człowieka jako samego człowieka" (Scheler, tłum. 1980, s. 322). Myśliciel twierdzi, że 
kwestia tego, czy, na ile i jak się rozumiemy, jest po prostu dla nas ważna. $\mathrm{Z}$ tego powodu powinna stać się przedmiotem rzetelnej i ze względu na swój charakter metasocjologicznej refleksji.

Scheler pozostaje świadom historyczności rozważań, które podejmuje. Wśród największych myślicieli należących do grona zainteresowanych tą tematyką wymienia Kartezjusza, Leibniza, Hegla i Hartmanna. I choć ich rozważań nie dyskredytuje, to dostrzega ich anachroniczność, niewystarczalność w czasach mu współczesnych. Metafizyczny indywidualizm monad i dusz, który dominuje w poglądach wymienionych fillozofów, nie wyjaśnia faktu, że przeżycia innego człowieka są nam - zwykle, bardziej lub mniej, w ten czy inny sposób - znane. Ludzie dani nam są jako jednostki coś przeżywające. Jako takie lub inne: zadowolone, zatroskane, zaniepokojone, nieszczęśliwe itd. Dlatego też Scheler znajdzie się w gronie tych myślicieli, którzy dostrzegli potrzebę filozoficznego opracowania tego zjawiska. A zarazem pośród tych, którzy zakwestionowali możliwość bezpośredniego wglądu we własne życie psychiczne. Dlaczego - zapyta - miałoby być oczywiste, iż każdemu dane jest przede wszystkim jego własne ja i jego przeżycia? „Cóż oznacza owo twierdzenie, że «każdy może myśleć jedynie swoje myśli, czuć swoje uczucia?» Co jest w nim «zrozumiałe samo przez się»?" (Scheler, tłum. 1980, s. 366).

Twierdzenia takie myśliciel uznaje za niepoparte empirycznie (niezgodne z tym, co dane), choć to one właśnie sprawiają, że wydaje nam się, iż aby poznać stan innego człowieka, musimy dokonać wielu karkołomnych zabiegów. Ich opis znalazł się w filozofii pod postacią dwóch wiodących i - według Schelera - błędnych koncepcji znajomości przeżyć innych. Pierwsza z nich to wnioskowanie o przeżyciach jakiegoś ty przez analogię z przeżyciami ja. Druga zaś to teoria ,wczucia”: wczuwania się w ciało (jego uczłonowanie, ruchy, ułożenie, mimikę) innego człowieka. Streśćmy krótko powody, dla których je odrzuca.

Zacznijmy od teorii wnioskowania przez analogię. Przeciwko niej przemawia to, że nawet zwierzęta rozpoznają stany innych (zarówno ludzi, jak i innych zwierząt), a przecież trudno byłoby je posądzać o proces umysłowy zwany wnioskowaniem przez analogię - to po pierwsze (Scheler, tłum. 1980, s. 356-357). Po drugie, inaczej dane nam są nasze własne ruchy wyrazowe, a inaczej ruchy wyrazowe innych. Te własne postrzegamy w postaci ,intencji ruchu i położenia”, a u innych jako „optyczne obrazy tych ruchów” (Scheler, tłum. 1980, s. 57-59). A jeśli tak, to nie możemy wnosić z ruchów 
innych o przeżyciach, które znamy na podstawie - innych - ruchów własnych. Po trzecie, przekonanie, że dana istota coś przeżywa, przypisujemy również tym, których ruchy wyrazowe są niepodobne do naszych, ludzkich (np. rybie lub ptasie). Tymczasem przeżycia zwierząt też są nam dane, bywa, że wydają nam się oczywiste (Scheler, tłum. 1980, s. 59-60). Konkludując, można stwierdzić, że znajomość innych przez analogię prowadzić mogłaby wyłącznie do wniosku, że istnieją jakieś inne ja o tyle, o ile są to takie same ja jak własne. Można, rzecz jasna, coś takiego twierdzić, ale nie o obronę tej tezy chodzi adwersarzom teorii wnioskowania przez analogię.

Podobnie ma się rzecz z teorią „wczucia” - ta również chybia celu. Wyjaśnienie sposobu, w jaki znamy przeżycia innych (reprezentowane np. przez Theodora Lippsa), mówi o tym, że znajomość owa zasadza się na procesie wczuwania się w zjawiska cudzego ciała. Pierwszy z wielu argumentów wysuniętych przeciwko tej teorii wskazuje na to, że ,zbiegnięcie” się naszych przypuszczeń co do przeżyć innego z nimi samymi (ich pokrycie się) byłoby kwestią czystego przypadku. Dlaczego bowiem mielibyśmy w cudzym ciele czuć to samo, co w swoim? Dalej: skąd wiemy, co czuje ktoś, kto jest na przykład postacią z portretu (,nie jest czystą realnością”)? Rozumiemy jego gesty, mimikę, nie mogąc przecież wczuć się w jego ,portretową” cielesność. Tak samo ma się sprawa z gestami aktorów, które rozumiemy, a które nie mogą być poparte prawdziwymi przeżyciami ludzi odgrywającymi (udającymi) określone przeżycia (Scheler, tłum. 1980, s. 61).

Jak widać zatem i ta teoria nie thumaczy naszej wiedzy o przeżyciach innych. Podobnie jak wnioskowanie przez analogię może upewnić nas wyłącznie odnośnie do tego, że własne $j a$ istnieje w innym ,raz jeszcze”, ale nie odnośnie do tego, że owo ja jest innym, nie moim ja. Co z tego wynika?

Krytyka Schelera, jak się zdaje całkiem słuszna, celnie mierzy w najsłabszy punkt owych teorii, a mianowicie w przekonanie, że aby znać przeżycia innego człowieka, jest konieczne, abyśmy znali ruchy jego ciała. Tymczasem jeśli weźmiemy pod uwagę zwykłe doświadczenie, to okaże się, że bywa, iż ciało odgrywa znikomą rolę w poznawaniu procesów psychicznych innych osób. Może też w ogóle nie odgrywać żadnej! Nie jest czynnikiem ani jedynym, ani koniecznym.

Również tam, gdzie są nam dane jakieś znaki i ślady jego (innego) duchowej działalności np. dzieło sztuki bądź wyczuwalna jedność zamierzonego działania, bez trudu uchwytujemy czynne Ja indywidualne (Scheler, thum. 1980, s. 362). 
Powodem zakwestionowania znajomości przeżyć innego człowieka na podstawie jego fizycznej strony jest niezgoda myśliciela na to, że postrzegamy w człowieku ciało i ducha w sposób odrębny. Nie oznacza to, że takie komponenty nie istnieją, znaczy natomiast, że jako oddzielone nie są w doświadczeniu (fenomenologicznie) dane.

Tym, co spostrzegamy u innych ludzi, z którymi żyjemy, nie są „wpierw” ani ,cudze ciała w sensie fizycznym” (o ile nie przeprowadzamy właśnie zewnętrznego badania lekarskiego) ani cudze „Ja” i „dusze”, ale jednolite całości, które naocznie widzimy (Scheler, thum. 1980, s. 391).

Czym są owe jednolite całości? Co uchwytujemy, postrzegając innego człowieka? Według Schelera nie jest to ciało (i nie jest to dusza). Tym czymś jest wyraz. Odnosi się to również do bytów pozaludzkich.

[...] „wyraz” jest czymś, co człowiek najwcześniej uchwytuje w bycie znajdującym się poza nim i że jakieś zjawiska zmysłowe wpierw ujmuje on o tyle, o ile mogą się w nich ,przedstawiać” psychiczne jednostki wyrazowe (Scheler, thum. 1980, s. 357-358).

Widząc innego, nie widzimy - na przykład - śmiejącego się ludzkiego ciała, tylko śmiejącego się człowieka. Dusza znajduje swój wyraz, ale trudno powiedzieć, że znajduje go ściśle w obrębie ciała. Uchwytujemy na przykład czyjeś spojrzenie ,dużo wcześniej niż bylibyśmy w stanie podać barwę czy wielkość «oczu»" (Scheler, tłum. 1980, s. 364). Widząc porozrzucane rzeczy w czyimś pokoju, możemy potraktować je jako wyraz stanu ducha tego, kto je w taki sposób zostawił. Wiedza na ten temat przybiera - co warto podkreślić - formy nawet bardzo wyrafinowane: ,widzę - pisze Scheler - nie tylko czyjeś «oczy», ale również to, «że on na mnie patrzy», a nawet, «że spogląda na mnie w taki sposób, jakby chciał uniknąć tego, abym widział, że on mnie widzi»"! (Scheler, tłum. 1980, s. 390). Dlatego też wyraz trzeba traktować jako wyraz stanu ducha innego człowieka, ale nie w sensie odwzorowania w ciele tego, co dzieje się w duszy. Skąd zatem pochodzi nasza wiedza o wyrazie?

Odpowiedź brzmi: nabywamy ją - jako małe dzieci - w procesie socjalizacji. Ucząc się rozpoznawać stany uczuciowe innych osób, uczymy się rozpoznawania wyrazu. Czego się wtedy uczymy? 
[...] „pierwotnie” płynie obojętny $w$ aspekcie Ja-ty strumień przeżyć, faktycznie zawierający nieoddzielone i wzajemnie przemieszane to, co własne, i to, co cudze; w tym zaś strumieniu stopniowo dopiero tworzą się stałe, ukształtowane wiry, które powoli wciągają w swoje kręgi coraz to nowe elementy strumienia oraz sukcesywnie, stopniowo $\mathrm{w}$ trakcie tego procesu, przyporządkowywane są różnym indywiduum (Scheler, thum. 1980, s. 368).

Scheler postuluje istnienie sfery, którą określiliśmy jako bezosobową sferę niczyją. Ów strumień przeżyć uznaje za fenomenem pierwotny - niczym niewarunkowany, dany. Z nim człowiek jako dziecko styka się jako pierwszym. Dziecko „chwyta” stany, takie jak radość, smutek, niebezpieczeństwo, ale nie przypisuje ich osobom. Zjawisko adresowania przeżyć Scheler uznaje za wtórne i mające swoją dalszą chronologię. „ «Wpierw» człowiek żyje bardziej w innych niż w sobie samym, bardziej we wspólnocie niż w swoim indywiduum" (Scheler, tłum. 1980, s. 369).

Jeśli zatem chodzi o kolejność dania przeżyć ludzkich w procesie nauki wyrazu, to najpierw dany nam jest wyraz, który nie ma adresata, później uczymy się go przypisywać innym, a na samym końcu sobie. Dowodem na to są według Schelera fakty z naszego dzieciństwa (jak też z życia psychicznego ludów pierwotnych). Gdy dziecko przychodzi na świat, całe jego życie psychiczne zależne jest od „,idei, uczuć, kierunków dążenia”, jakimi żyje jego otoczenie. Dziecko pozostaje ,wtopione w ducha rodzinnego". Następnie przybiera postać przeżyć konkretnego ty. Wtedy jeszcze własne życie duchowe pozostaje dla dziecka skryte! (Scheler, tłum. 1980, s. 369). Proces przyporządkowania siebie do strumienia przeżyć, w które jest zanurzone, wieńczy całą naukę. Rodzi się pytanie: dlaczego przeżycia początkowo pozostają nieprzypisane żadnym osobom?

Proces przypisania danego przeżycia konkretnej osobie polega, według Schelera, na obiektywizacji przeżyć, a to pociąga za sobą potrzebę zdystansowania się od otoczenia. Aby do tego doszło, świadomość dziecka musi najpierw zostać ,,wypełniona ideami i przeżyciami, których faktyczne pochodzenie pozostaje dla niego zupełnie nieznane" (Scheler, tłum. 1980, s. 370). Dla dziecka muszą zaistnieć ,schematy i formy życia psychicznego charakterystyczne dla danej wspólnoty”, by wtórnie je komuś przypisać. Jak ujmuje to Stanisław Czernik, Scheler przekonanie o realności społeczeństwa czy grupy społecznej uznaje za uprzednie w stosunku do samowiedzy indywidualnej. Uwaga ta odnosi się również do wiedzy o konkretnym ty: 
„Prymat grupy jest przy tym zawsze jednocześnie poznawczym prymatem «innego», który sytuuje się wobec indywiduum jako partner rozlicznych interakcji” (Czerniak, 1981, s. 105).

Dopiero bardzo powoli dziecko podnosi jakby swą własną duchową głowę z tego ponad nim przelewającego się nurtu i odnajduje się jako istota, która też ma własne uczucia, idee i dążenia (Scheler, tłum. 1980, s. 369-370).

A zatem - choć jest to dosłownie wywrotowe w stosunku do teorii wnioskowania przez analogię i „wczucia” - o myślach, które myślę, i uczuciach, które czuję, mogę powiedzieć, że są moje o tyle, o ile umiem je przypisać innym. To zaś umiem wtedy, kiedy znam je jako niczyje. Dana jest mi treść przeżyciowa jako zbiór możliwych wyrazów, adresat zaś jest kwestią późniejszą. Jest niczym znak, jakim opatrujemy strumień przeżyć, pozostający w istocie swojej bez wskazań co do właściciela.

Myli się zatem ten, kto wyobraża sobie, że człowiek wysnuwa z siebie, niczym pająk sieć, swe własne przeżycia. Jeśli jakiś obraz odnośnie do poglądów Schelera moglibyśmy tu przywołać, to będzie to obraz wypożyczalni (np. strojów). Nie jesteśmy - wbrew intuicjom ukutym przez tradycję - kreatorami naszych przeżyć, lecz ich depozytariuszami.

Wróćmy jednak do procesu socjalizacji, kiedy to dziecko uczy się wyrazu, by potem przypisać go jakiemuś ty lubja. Wyjaśniliśmy już, czego uczy się dziecko, by rozpoznawać określone przeżycia. Pozostaje jednak kwestia: jak?

Odpowiedź należy do najbardziej nowoczesnych myśli Schelera. Według niego dziecko uczy się wyrazu, ucząc się języka. Ten bowiem jest nam dany w pojęciach odnoszących się do przeżyć. (Fakt ten jest ważny $\mathrm{z}$ tego względu, że stanowi oś możliwego - i dokonanego w tym artykule - odniesienia do poglądów Wittgensteina). Nauka wyrazu, która decyduje o znajomości stanów psychicznych (czy to jego czy moich) ma charakter nauki rozpoznania ich na podstawie pojęć, które się wcześniej przyswoiło.

Skoro władza języka sięga głęboko w samotne i ciche życie duszy, tak że jeśli brakuje jednostki słownej lub innej przyjętej społecznie formy wyrazu przeżycia, to ono samo nie wyodrębnia się ze strumienia przeżywania (Scheler, tłum. 1980, s. 371). 
Proces ,zaznajomienia” się z bezosobową sferą niczyją, przyswojenia "wielkiego zbiorowego strumienia powszechnego życia psychicznego" (Scheler, tłum. 1980, s. 374) przybiera postać nauki pojęć psychologicznych (odnoszących się do naszego życia psychicznego). Myśl ta jest pewną postacią relatywizmu językowego. Język przestaje tu bowiem pełnić rolę lustra przeżyć. Staje się ich nośnikiem w tym sensie, że brak słów oznacza wprost ich brak (a nie odwrotnie).

Bezosobowa sfera niczyja w ujęciu Schelera dana jest poprzez język. Fakt ten ma niebagatelne znaczenie i rodzi pewne problemy. Język ulega zmianom: jedne pojęcia pojawiają się, inne zanikają lub przekształcają się. Jeśli zatem prawdziwa jest teza, że nasza wiedza o przeżyciach pochodzi $\mathrm{z}$ języka, to powstaje pytanie, skąd zatem biorą się w nim nowe pojęcia?

Odpowiedź Schelera różni się zasadniczo od tej, której - jak zobaczymy w dalszej części tego artykułu - udziela Wittgenstein. Twierdzi on, że nowe pojęcia, a zatem i przeżycia, wynajdują... poeci. To oni wzbogacają nasze życia psychiczne. Wprowadzają nowe słowa w obieg publiczny, a tym samym stają się „odkrywcami naszego życia psychicznego” (Scheler, tłum. 1980, s. 378). „Są tymi, którzy wprowadzają nowe segmentacje i uczłonowania w ujęciu strumienia i dopiero w ten sposób wskazują odbiorcom to, co przeżywaja" (Scheler, tłum. 1980, s. 378).

Proces wynajdywania „nowych segmentacji i uczłonowań zdań” polega - jak objaśnia to myśliciel - na ich wydzieraniu ze ,straszliwej niemoty naszego życia wewnętrznego" (Scheler, tłum. 1980, s. 379). To, co zwykle wykracza poza możliwości jednostki, u szczególnie wrażliwej udaje się. I choć na początku nowe formy wyrazu stosowane są przez niewielu - pozostają elitarne - to z czasem upowszechniają się podobnie jak towar w gospodarce. Sól czy herbata, na przykład, z początku były luksusem używanym przez nielicznych, a potem stały się towarem posiadanym powszechnie (Scheler, tłum. 1980, s. 378). I tak też jest $\mathrm{z}$ nowymi pojęciami. Poeci wynajdują je. a te upowszechniają się. Wittgenstein - jak zobaczymy - zaproponuje zupełnie inne rozwiązanie tego problemu.

Zanim przejdziemy do prezentacji tego rozwiązania, warto dodać jeszcze dwie uwagi. Po pierwsze, wątek poetów odgrywających tak doniosłe znaczenie dla samowiedzy życia psychicznego daje się ująć jako pewne uszczegółowienie Schelerowskiej teorii wzorów osobowych. Myśliciel utrzymuje bowiem, iż w każdej zbiorowości istnieją ludzie pełniący rolę wzorów dla innych. Leszek Kusak (2007, s. 193) w swoim podsumowaniu 
wymienia ich kolejno jako: artystów, przewodnich duchów cywilizacji, bohaterów (występujących jako filozof i mędrzec, prawodawca i sędzia). Osoby te - właściwe każdej epoce - są konkretnymi ludźmi, którzy „ucieleśniają” określone wartości o znaczeniu uniwersalnym. Dusze poetów, o których tu mowa, stanowią uniwersalny wzorzec duszy ludzkiej. Wskazują dla czasu, w jakim przyszło im żyć, granice możliwego przeżywania.

Kolejna uwaga dotyczy omówionej tu możliwości poznania drugiej osoby. Jej zrozumienie możliwe jest, co warto dodać, również w planie szerszym, etycznym. Rozumienie innego człowieka nie pozostaje li tylko faktem o charakterze epistemologicznym. Jego znaczenie polega na tym, że dzięki niemu zrealizowane zostają również pewne wartości. Rozumienie, znajomość duszy innego człowieka, może przyjąć postać głęboką, stając się wtedy porozumieniem. Tak o tym pisze Hanna Buczyńska-Garewicz:

Spotkanie osoby nie redukuje się ani do uczuć, ani do wiedzy, lecz jest bezpośrednią relacją sui generis. Jest ono ujęciem osoby w jej jedności i jedyności. Jest to takie ujęcie innego człowieka, które wykracza poza zwykłą wiedzę o nim, poza wszystkie fakty jego biografii. Scheler taki wgląd w drugiego człowieka nazywał znajomością jego ordo amoris (1992, s. 157).

\section{Wittgenstein}

Przywołanie Wittgensteina po Schelerze jest ze wszech miar zasadne, gdyż mówiąc słowami Petera Hackera: ,[...] żaden filozof nie wykazał większej wrażliwości na fenomenologię języka niż Wittgenstein” (thum. 1996, s. 33). Obaj znajomość przeżyć innego człowieka tłumaczą umocowaniem jej w sferze o charakterze powszechnym i językowym zarazem. Obaj wskazują na pojęcia jako właściwe źródło naszego życia psychicznego. Inaczej jednak - co zostało już zasygnalizowane - wyobrażają sobie mechanizm wzbogacania języka pojęć psychologicznych (a tym samym naszych przeżyć o nowe formy). „Przeskakując” prezentację poglądów Wittgensteina, które są zgodne z poglądami Schelera, skupmy się na tym, co ich różni. (Pogląd Wittgensteina na temat poznania własnego i cudzego ja został szczegółowo przedstawiony w: Gurczyńska, 1997). Zacznijmy więc od miejsca, w którym przerwaliśmy nasz tok rozważań i ponówmy pytanie inicjujące brak zgody 
pomiędzy myślicielami. W jaki sposób wzbogaca się język o nowe pojęcia psychologiczne?

Publiczny charakter języka należy do najmocniej podkreślanych przez Wittgensteina jego cech i wyrażony jest w słynnej tezie mówiącej o nieistnieniu języka prywatnego. Jeśli więc ten jest niemożliwy, niemożliwe jest prywatne, dokonywane w akcie sam na sam ze sobą (poety), nazwanie przeżyć. Wittgenstein wyklucza, aby możliwa była prywatna ceremonia łączenia doznania z wymyśloną nazwą. Nie „namierzamy” przeżycia skupieniem uwagi, by potem „ochrzcić go”. A tak, jak się zdaje, wyobrażał to sobie Scheler, który, widząc w poecie tego, kto wzbogaca język naszych przeżyć, pozostawał niekonsekwentny: głosząc tezę o publicznym charakterze języka, wyobrażał go sobie jako - chwilowo - prywatny. Wyjaśnijmy to, oddając najpierw głos Wittgensteinowi.

[...] przypuśćmy, że dziecko byłoby geniuszem i samo wynalazłoby nazwę dla doznania! - Co prawda, nie mogłoby się ono takim słowem porozumiewać. - Tak więc rozumie ono tę nazwę, ale nie może nikomu wyjaśnić jej znaczenia? - A więc co to ma znaczyć, że „nazwało ono swój ból"? - Jak się to robi: nazwać ból?! Cokolwiek dziecko tu zrobiło, jakiż to miało cel? - Gdy mówimy: „Nadało doznaniu nazwę”, to zapominamy, że wiele musiało być już przygotowane w języku, by proste nazywanie miało swój sens. Gdy mówimy, że ktoś nadał bólowi nazwę, to gramatyka słowa „ból” jest tym, co było przygotowane; wskazuje ona miejsce, w które wstawia się nowe słowo (Wittgenstein, thum. 1972, § 257).

Cytat ten jest bardzo ważny ze względu na zawartą w nim frazę: ,,wiele musiało być przygotowane". Aby nazwać to, co dotąd było nienazwane - a co stanowiło zadanie, z którego, według Schelera, wywiązywali się poeci - nie wystarczy, by tak rzec, wrażliwość nazywającego, wsłuchanie się w głos własnej duszy. Znalezienie nazwy nie jest - według Wittgensteina - sposobem na wzbogacenie języka. Rzecz cała nie jest też kwestią zdolności, geniuszu, wyjątkowości wglądu, głębi wrażliwości. Błąd Schelera, z perspektywy Wittgensteina, polega na tym, iż ten zakłada, że owszem, język jest medium publicznym, ale zanim taki się staje, to - na chwilę przynajmniej - jest prywatny. A to, zdaniem Wittgensteina, jest niemożliwe. Publiczny język nie ma prywatnego źródła. Jak zatem wzbogaca się go o nowe formy wyrazu? Wittgenstein odpowiada: aby się pojawiły, ,wiele musi być przygotowane”. Owo ,wiele” w wykładni Wittgenstein to gramatyka. 
Gramatyka w filozofii autora Dociekań filozoficznych to techniczne pojęcie oznaczające coś innego niż tylko zbiór reguł tworzenia poprawnych wypowiedzi. Tą określa mianem powierzchownej i odróżnia od głębokiej, oznaczającej sposób, w jaki używa się danego pojęcia. Sprawą gramatyki jest, że pytamy o to, jak się komuś spało, a nie pytamy, jak się komuś myślało, choć w sensie gramatyki powierzchownej pojęcia „myśleć” i ,spać” należą do tej samej kategorii. (Szerzej o różnicy pomiędzy gramatyką powierzchowną a głęboką można przeczytać w: Hacker, 1996, s. 36-40).

A zatem tym, co musi być przygotowane, aby pojawiły się nowe pojęcia, jest sposób, w jaki będzie się ich używało. Aby to wyjaśnić, trzeba przyjrzeć się temu, jak funkcjonują słowa w języku. Metaforą, za pomocą której Wittgenstein opisuje język, jest skrzynka z narzędziami (Wittgenstein, tłum. 1972, § 11). Znajdują się w niej narzędzia o różnym przeznaczeniu: jedne służą do cięcia, inne do wbijania, jeszcze inne do klejenia czy do mierzenia. Cięcie, wbijanie, klejenie i mierzenie - to różne, niesprowadzalne do siebie czynności. I tak jest też z wyrazami lub wyrażeniami w języku. Są takie, które służą do rozkazywania, inne do wyrażania wątpliwości, jeszcze inne pozwalają nam żartować lub wprawiać kogoś w zdziwienie. Wyjaśniwszy to, wróćmy do pytania o to, co musi się pojawić w języku, aby nazwać dane przeżycie, i zadajmy go, wykorzystując wprowadzoną metaforę. Będzie ono teraz brzmiało: co musi być przygotowane, aby pojawiło się nowe narzędzie?

Co poprzedza pojawienie się narzędzia? Odpowiedź, która natychmiast przychodzi nam na myśl, to potrzeba. Przed wynalezieniem dajmy na to strzykawki istniało zapotrzebowanie na instrument, za pomocą którego wprowadzi się płyn leczniczy bezpośrednio do komórek ciała. Przeznaczenie to - ze względu na cele zdrowotne, jakie miała spełniać - można by rzec, istniało od zawsze, czyli w tym wypadku od momentu pojawienia się człowieka mającego biologiczny, a więc narażony na choroby, organizm. A jednak - i tu można zacytować słowa Wittgensteina, których sensu poszukujemy - „wiele musiało zostać przygotowane”, aby potrzeba taka rzeczywiście zaistniała. Wynalazek strzykawki jest poprzedzony bezpośrednio określoną wiedzą medyczną o ciele ludzkim, lekach, ich transporcie w organizmie. Dalej: wiedzą dotyczącą higieny, bakteriologii, metod sterylizacji itd. Musiała zaistnieć technologia powstawania takiego instrumentu medycznego, jak strzykawka (pierwotnie szklana, z metalowym tłokiem, wielokrotnego użytku). Musiało wreszcie zaistnieć społeczne urządzenie służące do po- 
dawania leków tego typu. Przy jej upowszechnieniu duże znaczenie miał również jej koszt, który musiał „wpisać się” w ogólną ekonomię leczenia itd. Jak widać, sama potrzeba to zbyt mało, aby pojawił się instrument jej odpowiadający.

O tym, że to nie „naga” potrzeba jest przyczyną pojawienia się nowości, niech świadczy również i to, że wynalazek tłokowej strzykawki, obecnie szeroko rozpowszechnionej, dokonał się właściwie przypadkiem - a zatem nie bezpośrednio po to, by zaspokoić swe przyszłe przeznaczenie. Francuski lekarz Charles Pravaz w 1853 roku pracował nad leczeniem tętniaków, wstrzykując do tętnic chlorek żelazowy. Metoda ta okazała się nieskuteczna, ale jako ,produkt uboczny" badania te pozostawiły po sobie metalowy walec $\mathrm{z}$ tłokiem w środku. Instrumentem Pravaza zainteresował się szkocki lekarz Alexander Wood, który dołączył do niej cienką, ściętą na końcu igłę. Tak uzbrojona strzykawka służyła początkowo (najprawdopodobniej) wyłącznie do podawania morfiny (w tym celu użyto jej po raz pierwszy), by potem znaleźć szerokie zastosowanie jako instrument dokonywania zastrzyków z wszelkich płynów leczniczych. Jako taka znalazła dalsze zastosowanie: służyła podawaniu szczepionek i pobierania płynów ustrojowych, biopsji i płukaniu cewników. I ewoluowała dalej: pojawiły się strzykawki automatyczne podające precyzyjnie określone dawki insuliny. Przed strzykawką jest też przyszłość: w projekcie znajdują się takie, które minimalizują groźbę zakażeń. (Więcej o wynalazku strzykawki w: Durek, Pawela, Wnukiewicz, 2008, s. 85-88).

O tym, jak ,wiele musiało być przygotowane”, aby strzykawka została wynaleziona, świadczy również jej prototypowa postać. Za czasów Hipokratesa istniał przyrząd składający się z pęcherza zwierzęcego, z którego biegła rurka, a z niej z kolei wypływał leczniczy płyn. Do tego, by zaistniała w swojej późniejszej postaci, w czasach starożytnych $z b y t$ mało byto przygotowane. Czas dla niej jeszcze nie nadszedł i nie miało to nic wspólnego z tym, że nie było na tyle zdolnych wynalazców, aby do jej wynalazku doprowadzić!

Co pomaga nam zrozumieć ta rozbudowana analogia? Otóż tak jak strzykawka nie pojawiła się ex nihilo w wyniku zdolności geniusza, który wynalazł ją, skoncentrowawszy swe twórcze wysiłki na potrzebie, tak też słowa nie pojawiają się w języku twórczą mocą poetów. Nazywanie doznania nie odbywa się poprzez wgląd w stan własnego umysłu, a następnie nadanie mu nazwy. Według Wittgensteina taka ceremonia to ostatnie i mało istotne 
posunięcie w grze językowej, która musi być już w toku, by do nazywania doszło. Wymaga ono szerokiego kontekstu, który to umożliwi. Tego właśnie, jak się zdaje, nie dostrzegał Scheler, a dostrzegł i opisał Wittgenstein. Bez odpowiedniego „otoczenia” poeta, największy z największych, pozostałby niemy.

Czemu moja prawa ręka nie może podarować lewej pieniędzy? - Moja prawa ręka może je do lewej włożyć. Moja prawa ręka może wypisać poświadczenie darowizny, a lewa pokwitowanie. - Jednakże dalsze konsekwencje praktyczne nie byłyby tu konsekwencjami darowizny. Gdy lewa ręka wzięła pieniądze z prawej itd., wówczas spytamy: „No i co dalej?”. To samo pytanie można by też postawić, gdy ktoś objaśnia sobie prywatnie jakieś słowo, tzn. gdy je wymawia, kierując przy tym uwagę na pewne doznanie (Wittgenstein, tłum. 1972, § 268).

Jest oznaką fundamentalnego nieporozumienia, jeżeli po to, by wyjaśnić sobie filozoficzny problem doznania, skłonny jestem badać swój aktualny stan bólu głowy (Wittgenstein, tłum. 1972, § 314).

Znajomość przeżyć własnych nie jest - jak mogłoby się wydawać - samoznajomością. Nie polega na samodoświadczeniu. Doznawać, mieć określone przeżycia, u Wittgensteina znaczy: brać udział w grze językowej. Na wyrażenia takie, jak na przykład: „nagle coś zrozumieć”, „ulec chwilowej słabości”, ,wziąć na siebie odpowiedzialność”, należy spojrzeć jako na posunięcia w grach, które wymagają czegoś więcej niż czującej duszy. Jak słusznie zauważa Cavell: ,[...] nie możesz powiedzieć dziecku, co znaczy słowo, kiedy dziecko nie nauczyło się jeszcze, czym jest «pytanie o znaczenie» (tj. jak pytać o znaczenie), podobnie jak nie możesz pożyczyć grzechotki dziecku, które nie nauczyło się jeszcze, co znaczy «pożyczyć coś od kogoś (lub komuś)»»" (Cavell, 2000, s. 35). Posunięcie w grze zakłada jej cały kontekst. Tak o tym pisze Finch:

Tym, co wiąże gry językowe i formy życia, nie są reguły, lecz jeszcze szerszy zakładany przez nie kontekst codziennego życia i codziennej pewności, co Wittgenstein rozważa w swej ostatniej pracy $O$ pewności. Jak tam podkreśla, ów kontekst nie jest czymś, o czym „wiemy”, lecz ramą, wewnątrz której znajduje się to, że coś wiemy i w coś wątpimy, nasze sądy i dociekania. Jest on tym, co „trwałe”, jak język i warunki, w które rzucone są nasza wiedza i nasze problemy. (Finch, 1996, s. 104). 
Spróbujmy przyjrzeć się bliżej owemu kontekstowi, czyli temu, co musi być przygotowane, aby mogło dojść do nazywania (albo w ogóle do użycia nazwy). W tym celu odejdźmy od tekstu Wittgensteina i posłużymy się słowami jednego z najznakomitszych przedstawicieli interakcjonizmu symbolicznego.

\section{Goffman}

Erving Goffman, który podobnie jak Ludwig Wittgenstein określa kontekst społeczny, w obrębie którego ludzie porozumiewają się ze sobą mianem gry, czyni to w sposób bardziej skondensowany. Jego dzieło Człowiek $w$ teatrze życia zaczyna się następująco:

Kiedy jednostka gra jakąś rolę, oczekuje od obserwatorów, że wrażenie, jakie pragnie w nich wywołać, odbiorą zgodnie z jej zamysłem. Wymaga od nich, by uwierzyli, że oglądana przez nich postać rzeczywiście posiada cechy, które zdaje się posiadać, że wykonywane przez nią zadanie będzie miało efekty zgodne z zadeklarowanym zadaniem oraz, że w ogólności rzeczy mają się tak, jak je przedstawia. Bezpośrednio z tym łączy się rozpowszechniony pogląd, że jednostka występuje i organizuje „widowisko dla innych ludzi” (Goffman, tłum. 2000, s. 47).

Tym, co zwraca uwagę w cytowanym fragmencie, jest mało akcentowany w literaturze filozoficznej fakt (Wittgenstein należy tu do wyjątków), że człowiek okazuje swoje przeżycia, gdyż inaczej nie mógłby skomunikować się z innymi. Zgodnie z metaforą Goffmana bierzemy udział w przedstawieniu, które odbywa się dla innych. Uczestniczymy w nim niezależnie od tego, czy tego chcemy, czy nie. Intencjonalnie lub bezwolnie ,organizujemy" widowisko dla innych. Nie znaczy to oczywiście, że jesteśmy zawsze nieszczerzy, że udajemy i staramy się wyprowadzić innych w pole. Bywa, iż jesteśmy szczerzy, bywa, iż udajemy, niezmienne zaś pozostaje to, że „wywołujemy jakiś efekt”. Czasami staramy się, żeby był zgodny z naszymi oczekiwaniami, a czasami jest nam to obojętne.

Przeżycia, w proponowanej przez Goffmana wykładni, są rodzajem steru, za pomocą którego kierujemy przekonaniami publicznymi. Możemy je wykorzystywać, świadomie je przerysowując, udając lub ukrywając coś. Możemy też nie być świadomi efektu, jaki wywołujemy. Możemy pozostać 
naturalni. Tak czy inaczej pozostają one częścią gry, czyli że warunkuje je kontekst, który wykracza poza subiektywne cele i działania jednostki. Co go tworzy?

Za Goffmanem można odpowiedzieć, iż kontekst ów tworzą dekoracje, a więc ,meble, sprzęty i inne elementy, które składają się na scenerię i rekwizyty sceniczne wykorzystywane przez jednostkę podczas przedstawienia" (Goffman, tłum. 2000, s. 52). Poza dekoracjami jest coś, co autor określa mianem „fasady osobistej”. Składają się na nią ,insygnia związane z pozycją i urzędem, strój, wiek, płeć, cechy rasowe, postura i wygląd, sposób mówienia, mimika, gesty" (Goffman, thum. 2000, s. 53-54). Wszystkie te elementy decydują o wrażeniu, jakie, chcąc nie chcąc, wywieramy na innych.

Gra toczy się ze względu na związki pomiędzy jej określonymi elementami. Może być tak na przykład, że insygnia statusu społecznego pozostają w sprzeczności z powierzchownością lub sposobem bycia jednostki. (Na przykład jej ubiór nie licuje z ceremonią, w której bierze udział lub mimika nie odpowiada dekoracjom). Związki te ustanawiają się zgodnie lub niezgodnie z życzeniami człowieka. Ten może nie zauważać, że jego gesty nie licują ze strojem, sposób mówienia z urzędem itd. Wtedy związki te ustanawiają się same. Ale bywa też na odwrót: człowiek może nimi sterować, robiąc na przykład odpowiednią minę do odpowiedniej gry. Tak czy inaczej, efekt sceniczny wykracza poza to, co można by nazwać samym stanem psychicznym jednostki.

To, czego wymaga się od jednostki, to wyuczenie się pewnej ilości „chwytów”, wystarczającej do „wypełnienia” i dania sobie rady w mniejszym lub większym stopniu z każdą rolą, jaka mu może przypaść w udziale. Autentyczne występy w życiu codziennym nie są ,grane” czy „wystawiane” w tym sensie, że ich wykonawca wie z góry, co będzie robił, i robi to jedynie ze względu na efekt, który chce uzyskać. Wrażenie, jakie czuje, że wywiera, jest mu w jakimś sensie niedostępne. [...] Krótko mówiąc, wszyscy lepiej gramy, niż wiemy, jak mamy grać (Goffman, thum. 2000, s. 103).

Metafora teatru, dekoracji, rekwizytów itd. obrazuje, w jak bogatej scenerii dochodzi do odczytania tego, co nazywamy stanem psychicznym jednostki. Jak dalece efekt jest zdeterminowany czymś, co jednostka kontroluje tylko częściowo. Jak wykracza, mniej lub bardziej, poza jej bezpośrednie intencje. Kontekst - co ważne - pozostaje konstytutywny 
nie tylko dla recepcji przeżyć (dla widza w teatrze życia), ale również dla przedstawiającego.

Kiedy aktor przyjmuje określoną rolę społeczną, zdaje sobie zazwyczaj sprawę, że przypisana jest już do niej określona fasada. Niezależnie od tego, czy przyjął już tę rolę po to, by wykonać określone zadanie, czy też po to, by utrzymać odpowiadającą temu zadaniu fasadę, przekonuje się, że musi robić zarówno jedno, jak i drugie (Goffman, tłum. 2000, s. 57).

Ważne jest to, że niezależnie od tego, czy jednostka świadomie wykorzystuje określone elementy sceniczne, czy też czyni to nieświadomie lub spontanicznie - niezmienne pozostaje, że nie jest „doczepiona” do scenerii, mogąc mieć te same przeżycia poza nią. Życia psychicznego nie wnosimy na scenę, mając go wcześniej poza nią. (Sceneria owa, która pozostaje istotna dla sensu danego przeżycia, nie ma ostatecznych granic. Dlatego też część komentatorów prac Wittgensteina mówiąc o scenerii, kontekście lub otoczeniu, które decydują o treści przeżycia, twierdzą, że chodzi tu o kulturę, w której żyje człowiek, zob. np. Mulhall, 1993, s. 63). Życie psychiczne jest wkomponowane w całość życia społecznego, dlatego też nie może toczyć się w separacji. By mieć określone przeżycia, uczucia, doznania - sama dusza to byłoby za mało. Poprzedza je kontekst - bezosobowa sfera niczyja. To ona pozostaje warunkiem pojawienia się jakichkolwiek przeżyć łącznie z tymi nowymi. I jako taka nie ma swego wynalazcy.

Ceremonia nazywania, która pojawia się u Schelera, jest końcem procesu, podobnie jak wygłoszenie kwestii na scenie jest końcem długich przygotowań. Kontekst, który pozwala na nazywanie, wykracza poza jednostkową duszę. Jej przeżycia zakotwiczone są w nim, sferze, która nie ma swojego autora, nie ma charakteru osobowego, nie ma swojego „kto” - pozostaje niczyja. Potrzebuje natomiast aktorów, którzy grę „ożywiają”, wiążą ją, stając się niezbędni na scenie, aby ta mogła się toczyć.

\section{Podsumowanie}

Choć życie psychiczne ma charakter osobowy - przypisujemy je określonej osobie - to nie jest prywatne. „Zakotwiczone” jest w czymś znacznie szerszym niż jakiekolwiek ja, które tradycja uznała za jego oczywiste źródło. 
Wbrew niej na przełomie XIX i XX wieku dostrzeżona została społeczna natura tego, co uznać można za macierz naszych przeżyć. W pismach myślicieli współczesnych pojawia się sfera bytowa, która ma powtarzające się charakterystyczne rysy: jest ponadindywidualna, ale nie uniwersalna, bezosobowa i niczyja. Pojawia się jako odpowiedź na pytanie o genezę naszej wiedzy o przeżyciach, zarówno „własnych”, jak i „cudzych”, i rozwiązuje paradoksy wynikające z dotychczasowych ustaleń. Można powiedzieć, że „zamyka usta" wiodącym spór o to, czy i skąd znane jest życie psychiczne innych ludzi. Pytania o to, czy mogą być mi znane uczucia, których nie czuję, myśli, których nie myślę, doznania, których nie doznaję - wraz z przyjęciem nowej wykładni - okazują się źle postawione.

Przeżycia, o których mówię jako o moich/twoich/jego/ich itd., nie są moje/twoje/jego/ich itd. w sensie, jaki się nasuwa w związku z użyciem słowa „mieć”. Przytoczone poglądy Nietzschego, Schelera, Wittgensteina, Goffmana - choć w różny sposób - skłaniają ku temu, by spojrzeć na życie psychiczne nie jak na akty czy też procesy przebiegające w naszym wnętrzu, lecz jak na integralną część ceremonii społecznych, powtarzalnych, mających różne warianty i... zrozumiałych dla innych uczestników. Przeżycie, pojmowane tradycyjnie jako coś przez nas posiadanego, bo zachodzącego w naszym wnętrzu, zostaje ukazane jako ,posunięcie” w grze społecznej, jako próba osiągnięcia określonego celu, jak też jako sposób prezentacji, manifestacji swojego ja. W przeciwieństwie do tradycyjnego poglądu życie psychiczne przedstawione jest nie jako immanentne, ale jako coś, co ma swe źródło poza jednostką. Ta bowiem jest częścią bogatej scenografii, na którą poza nią składają się: rekwizyty, insygnia, osobista fasada, a wreszcie inni aktorzy, których kwestie, mimika i zachowanie - jeśli tylko pozostają zgodne z regułami ,gry" - są dla pozostałych zrozumiałe.

Wielką zasługą Nietzschego jest wprowadzenie pojęcia świadomości jako lustra, w którym odbija się nie indywidualne ja, lecz pewne my. Myśliciel „odwraca” w ten sposób kierunek, w jakim biegnie ludzkie poznanie, wprowadza ideę ja, które jest naturalnie zwrócone ku tym, z którym dzieli swą egzystencję. Wątek ten znajduje swoje odzwierciedlenie u Schelera, który postuluje istnienie wielkiego strumienia wspólnych przeżyć, będącego macierzą naszego zbiorowego życia psychicznego. Powszechność owej sfery zostaje u niego podkreślona sposobem, w jaki jest nam dana. Jej publiczny charakter znajduje swój wyraz w publicznym charakterze języka, który tym samym staje się nośnikiem naszego życia psychicznego. A jest nim 
wtedy również, kiedy pojawiają się w nim nowe, nieznane dotąd pojęcia psychologiczne. Ich genezę dostrzega w akcie dopasowywania nazwy do nienazwanego dotąd przeżycia. Ową , ceremonię” Wittgenstein uznaje za najmniej znaczący element procesu pojawiania się nowego słowa. Procesu tego nie może zainicjować jednostka, jako że ma on swoje źródło poza nią i jej twórczymi zdolnościami. W ten sposób autor Dociekań filozoficznych mocniej (i bardziej konsekwentnie) wspiera tezę dotyczącą istnienia bezosobowej sfery niczyjej, która wykracza poza pojedynczego człowieka, choć przemawia jego ustami. Pojawia się obraz istoty ludzkiej, która jest częścią gry i której gra nie odbywa się w próżni. Do tego bowiem, by ta się potoczyła nieco inaczej niż dotychczas, ,wiele musi być przygotowane”. Pogląd ów znajduje odzwierciedlenie w myśli Goffmana, który to, co nazwalibyśmy tradycyjnie wewnętrznym życiem jednostki, ukazuje jako integralną część gry, której celem jest efekt sceniczny, a wraz z nim określone profity społeczne. Nasze przeżycia, niezależnie od tego, czy okazujemy je szczerze, czy też udajemy, stają się rodzajem steru, za pomocą którego kierujemy przekonaniami innych ludzi.

Na koniec należy zapytać, czy ów „sznureczek” nazwisk pojawia się przypadkowo? Czy jest koincydencją, że poglądy owych myślicieli tworzą pewną komplementarną historię, w której jeden dopowiada to, czego nie powiedział inny, pozostając w zgodzie z głównym jej postulatem (istnienia bezosobowej sfery będącej macierzą naszego życia psychicznego). Co więcej, łańcuszek ten - gdyby nie ramy tego artykułu - można by wydłużyć o kolejne nazwiska (np. Sartre'a, Heideggera, Foucaulta i innych), uzyskując historię bardziej skomplikowaną, ale z łatwo dającym się wyodrębnić wątkiem głównym. Czy jest to przypadek? Otóż wydaje się, że można mówić w tym wypadku o duchu epoki, który niczym choroba zakaźna infekuje umysły swoich przedstawicieli. Epoki, w której aprobuje się pewne rozwiązania, a wyklucza inne. Filozofowie, parafrazując treść niniejszego artykułu, braliby udział w czymś, co wykracza poza ich indywidualne dusze, i pisaliby, czerpiąc z tego, co zostało dla nich ,wcześniej przygotowane”. I nie chodzi tu o tradycję byłą, ale o tę tworzoną aktualnie, niejako przez dopowiadanie zdań przez innych zaczętych. Tak jakby epoka miała coś do powiedzenia i nie mogła się zamknąć, dopóki nie zostałoby dopowiedziane ostatnie jej słowo. Ale wtedy - pamiętajmy - owo słowo nie byłoby ostatnie. 


\section{Bibliografia}

Buczyńska-Garewicz, H. (1992). Milczenie i mowa w filozofii. Warszawa: IFiS PAN.

Czerniak, S. (1981). Socjologia wiedzy Maxa Schelera. Warszawa: PWN.

Cavell, S. (2000). Dygresja o Wittgensteinowskiej wizji języka. W: A. Crary, R. Read (red.), Wittgenstein - nowe spojrzenie (s. 33-53). Thum. T. Zarębski i in. Wrocław: Wydawnictwo Naukowe Dolnośląskiej Szkoły Wyższej.

Goffman, E. (2000). Człowiek w teatrze życia. Tłum. H. Datner-Śpiewak, P. Śpiewak. Warszawa: KR.

Durek, G., Pawela, T., Wnukiewicz, J. (2008). Zarys wiedzy o strzykawce lekarskiej. Prace Historyczne, 45, XXX.

Gurczyńska, K. (2007). Podmiot jako byt otwarty. Problematyka podmiotowości w późnych pismach Wittgensteina. Lublin: Wydawnictwo UMCS.

Finch Le Roy, H. (1996). Formy życia. W: Metafizyka jako cień gramatyki (s. 91-105). Tłum. S. Kijaczko. Wrocław: Wydawnictwo Uniwersytetu Wrocławskiego.

Hacker, P.S.M. (1996). Ludwiga Wittgensteina późna koncepcja filozofii. W: Metafizyka jako cień gramatyki (s. 11-48). Tłum. S. Kijaczko. Wrocław: Wydawnictwo Uniwersytetu Wrocławskiego.

Kusak, L. (2007). U źródeł współczesnej filozofii człowieka: Kant i Nietzsche. Kraków: Wydawnictwo Akademii Ekonomicznej.

Mulhall, S. (1993). On being in the world. London-New York: Routledge.

Nietzsche, F. (1910-1911). Wiedza radosna. Tłum. W. Berent, K. Drzewiecki, L. Staff, S. Wyrzykowski. Warszawa: Nakład Jakóba Mortkowicza.

Scheler, M. (1980). Istota i formy sympatii. Tłum. A. Węgrzecki. Warszawa: PWN.

Wittgenstein, L. (1972). Dociekania filozoficzne. Tłum. B. Wolniewicz. Warszawa: PWN.

Żelazny, M. (2007). Nietzsche „ten wielki wzgardziciel”. Toruń: Wydawnictwo UMK. 
UNOWNED AREA AS A SOURCE OF MENTAL LIFE:

NIETZSCHE, SCHELER, WITTGENSTEIN, GOFFMAN

\section{Summary}

Traditionally mental life of the person goes into "seclusion" called his/her interior. It is believed that because of its secret nature of the it and because it is not immediately given to other subject who may - at best - guess of what "goes in". Free access one has got only to his/her own experiences (feelings, emotions, thoughts etc.). In the twentieth century (and a bit earlier) this traditional view is criticized and changed. As a fruit of this criticism emerged the opposite trend: the knowledge of both my and his/her inner experience is explain by introducing an element that allows this knowledge and is placed outside any of them. I call it the impersonal sphere of nobody - supra-individual matrix of the knowledge of my and his/her mental life. In this article I try to indicate the origin of the idea of this sphere giving its main characteristics. A description is based on the views of known philosophers: Nietzsche, Scheler and Wittgenstein and one sociologist - Goffman. 